\title{
The Reception of American Literature in Cameroon
}

\author{
Manyaka Toko Djockoua ${ }^{1}$ \\ ${ }^{1}$ Department of English, University of Yaoundé I, Yaoundé, Cameroon \\ Correspondence: Manyaka Toko Djockoua, Department of English, University of Yaoundé I, Yaoundé, \\ Cameroon. E-mail: manyaka.toko@yahoo.com
}

Received: August 26, 2014

doi:10.5539/hes.v4n6p15
Accepted: October 14, $2014 \quad$ Online Published: November 13, 2014

URL: http://dx.doi.org/10.5539/hes.v4n6p15

\begin{abstract}
In Cameroon, popular belief associates American literature with its country's economic and political greatness. Yet, if millions of Cameroonians show a growing enthusiasm for a visit to the US, just a few are interested in learning its literature. Using theories on the reading and teaching of literature, statistical data based on a questionnaire, as well as mythological and comparative approaches to literature, this paper intends to point out the various causes of Cameroonian students' lukewarm response to this literature and suggest some remedial strategies that may improve the reception of this discipline in Cameroon. The strategies recommended include the action of the Yaoundé-based American and Cameroonian officials, action which can foster the readers' and scholars' greater exposure to this discipline; the use of new technologies in the teaching of literature, which today, more than yesterday, has become a multimedia affair (Purves, 1997); and the comparative approach to the study of literary texts, as this approach connects American literature to the Cameroonian learners' experience.
\end{abstract}

Keywords: reception, response, American literature, strategies, reading, teaching, comparative approach

\section{Introduction}

Responses to literature vary according to its relation to the readers' and learners' experiences, interests and goals, as well as the methods used to teach it. Richter $(2000$, p. 24) posits that "our view of the world is not given but chosen." As a consequence, if one chooses to read a particular author, he/she chooses to espouse the latter's worldview. Espousing an author's worldview implies that his/her text appeals to the reader's experiences, interest and goals, as "most of us think of 'why we read' in terms of our immediate goals. Reading for a term paper, reading for pleasurable escape, and reading in search of a philosophy of life" (p. 24). Reading and learning literature thus bring along the following questions: why does one read and learn literature? Which texts should one read or learn? How should one read or learn them? And how should literature be taught? (Gadamer, 1989; Graff, 1992; Langer, 1994; Purves, 1997). Quoting Oslon and Torrance (2009), Singh (2014) points out that "different readers in different historical periods or in different cultural contexts might create and engage with written documents in dramatically distinctive ways." This statement highlights the fact that responses to literary texts are dependent on the readers' and learners' sensibility and motives.

The United States of America has established popularity among many students and scholars in Cameroon, yet few are interested in its literature. Even if there is presently a slight increase in the number of students who major in American Literature, the reception of the latter is still poor in Cameroon. This article will therefore answer the following questions: What is American literature? What are the causes of the poor reception of this literature in Cameroon? What can be done to stir the Cameroonian students' and scholars' interest in this discipline? Nkwetisama (2013) has investigated the role that literary texts may play in enhancing Francophone students' learning of the English language. Yet his analysis does not focus on the teaching of American literature, but on the use of English literary texts in teaching language. Very little research has therefore been carried out on the reception, reading and teaching of American literature in Cameroonian academic institutions. This article will consequently serve as an eye opener to some Yaoundé-based American officials, Cameroonian curriculum planners and educationists. The U.S. is one of the main countries that sponsor educational programs in Cameroon and one of these programs is the Susi Program on Contemporary American literature.

Before delving into any discussion about the reception of American literature in Cameroon, it seems necessary to give a brief overview and definition of this discipline, which some readers and scholars circumscribe either to a few African American writers or to some European American writers. To the Cameroonian layman, it is a sort of mystery. 
American literature has been influenced by the vision that the first European explorers had of the New World. Christopher Columbus, Bartolomé de las Casas, Hernán Cortés and John Smith, to name just a few, all represented this world as a land of plenty, the world's breadbasket. This vision, while it projected the material wealth of America, completely ignored the cultural wealth of this land, even if the latter was manifest in the numerous gifts that the Indian communities offered to the European explorers. Failure to acknowledge the rich Indian cultures ipso facto led to the rejection of Native American literatures, which were basically oral, even if the Aztecs had a long writing tradition. As Kenneth M. Roemer $(2005$, p. 4) observes, "before the arrival of Columbus, there were thousands of narratives, ceremonies, songs, and speeches performed by experts trained in performance and interpretation." The first explorers' vision of America was perpetuated by the pilgrims, the Puritans and some eighteenth- century writers like J. Hector Saint John de Crèvecoeur in Letter III, "What Is an American?" of his book Letters from an American Farmer (1782). Taming the new found rich and virgin land in order to transform the agrarian colony into an industrial nation took most of the European immigrants' time and forcibly made the literature lag behind the country's tremendous economic growth. This fact thus explains why the English critic Sydney Smith, quoted in Conn (1989, p. 13) could make such a contemptuous remark in Edinburgh Review in December 1818:

Literature the Americans have none-no native literature, we mean. It is all imported. They had a Franklin, indeed; and may afford to live for half a century on his fame. There is, or was, a Mr. Dwight, who wrote some poems; and his baptismal name was Timothy. There is also a small account of Virginia by Jefferson, and epic by Joel Barlow-and some pieces of pleasantry by Mr. Irving. But why should the Americans write books, when a six weeks' passage brings them in our own tongue, our sense, science and genius, in bales and hogsheads?(Note 1)

This statement is negation of American literature, negation that is emphasized in the question: "In the four quarters of the globe, who reads an American book?" (p. 114). Smith's remarks were a challenge to American intellectuals who answered the English critic's question by building a literature which matched the political and economic greatness of the US. From the nineteenth century that marked the American Renaissance to the twentieth and twenty-first century that consolidated its flowering, many theorists and innumerable writers: Ralph Waldo Emerson, Edgar Allan Poe, Walt Whitman, Ezra Pound, T.S. Eliot, W.E.B. Dubois, Countee Cullen, Saul Bellow, Toni Morrison, Eugene O' Neill, August Wilson, N. Scott Nomaday, to name just a few, proved to the world that there effectively exists a literature called American literature characterized by its immensity and diversity.

This literature is a multicultural and multi-ethnic postcolonial literature. It is the first postcolonial literature that claimed its national identity and thus sought to assert its independence from the grip of its colonial master. The US was the first postcolonial society to develop a national literature. This raised questions about the relationship between literature and place, between literature and nationality, and particularly about the suitability of inherited literary forms. The American experience served as a model for later postcolonial writing (Ashcroft, Griffiths, \& Tiffin, 1980, p. 16). American literature is the mode of expression of the Native American, European American, African American, Jewish American, and Asian American. It expresses the sensibilities of the numerous immigrants and their descendants who today constitute a population of about 311,591,917 (Source: U.S. Census Bureau, Jul. 2011).

Since the dawn of humanity, literature has underpinned the birth and growth of nations and nation states. Like other national literatures, American literature has backed the birth and expansion of the American nation by conveying its political, economic and cultural values beyond its national boundaries. The impact of the first explorers' vision on American literature was therefore not circumscribed to the US. Moving beyond its national boundaries, this vision also determined the African and specifically the Cameroonian reader's appeal to this literature. As a consequence, for many Cameroonians, the US is a land of promise in terms of job and financial opportunities. But to tap the economic resources of the US, it seems necessary for the Cameroonian - both at home and in the Diaspora- to understand the cultural and social history of this country. Literature is one of the means that can provide him/her with this information, as it represents the responses of Americans at the various periods of their country's history that includes politics and economics. The subsequent sections of this article will thus examine the theoretical framework and methodology used, the results of the questionnaire, and the comparative analysis of two short stories, which serves as a case study.

\subsection{Theoretical Framework}

This investigation will use Richter's, Gadamer's, Graff's, Purves's, and Langer's theories on reading and teaching literature as well as mythological and comparative approaches to literature. Gayatri Chakravorty Spivak (2003) 
argues that comparatists transcend the nation-based approach and adopt a cross-cultural approach that goes beyond national boundaries. According to Steven de Zepetnek Tötösy (1998), comparative literature may be the remedy against the contemporary paradox of globalization versus localization. The comparative approach to literature can therefore be a means to acquaint Cameroonian students with American authors and texts. The mythological approach will provide the rationale for a comparative study of two short stories by writers of different cultural backgrounds.

Alan W. Watts (1954, p. 7) defines myth as "a complex of stories-some no doubt fact, and some fantasy - which, for various reasons, human beings regard as demonstrations of the inner meaning of the universe and of human life" (7). As for Philip Wheelwright, quoted in Tate (1960, p. 11), "myth is the expression of a profound sense of togetherness of feeling and of action and of wholeness of living." From these definitions, Guerin, Labor, Morgan, Reesman, Willingham (1999, p. 160) conclude that "myths are by nature collective and communal; they bind a tribe or a nation together in common psychological and spiritual activities"). As for the archetypes, Gustav Carl Jung (1969, pp. 349-350) relates them to the unconscious and compares the latter to a collective human being combining the characteristics of both sexes, transcending youth and age, birth and death, and, from having at its command a human experience of one or two million years, practically immortal...It would have lived countless times over again the life of the individual, the family, the tribe, and the nation, and it would possess a living sense of the rhythm of growth, flowering, and decay.

It thus appears clear that myths and archetypes are inherent in all human societies. They are shared by the writers and their readers since they are forms or patterns in the human psyche. Jung's contention thus explains the universality of myths and archetypes, and their concomitant presence in world literatures. Gadamer (1989) purports that the reader or learner understands better the works of the past if he connects them to the present. His argument is relevant to the reading, learning and teaching of literature, as a literary work of the past is of interest to a reader if the latter can relate it to his/her present life. The study of a short story by a Native American writer alongside that of his Cameroonian counterpart will thus show that both tales handle issues that are of interest to the twenty-first century Cameroonian reader.

\section{Methodology}

\subsection{Data Collection and Population}

The questionnaire used as a research tool consists of close and open-ended questions. It was distributed to second year /level two students of the Department of English of the Faculty of Arts, Letters and Social Sciences of the University of Yaoundé I. This sampling is representative of the students' population of the University. It was chosen because the students of this level are likely to be exposed to more American literary texts than the students of level one, who are just from high schools, and those of levels three, four and five. At the latter levels, the number of respondents is reduced as students are given the opportunity to choose other literatures as their majors. The questionnaire below was administered to a sampling population of 191 students during lecture hours to maximize the chances of having a maximum number of respondents. To preserve their anonymity, the respondents were asked not to write their names on the questionnaire paper.

\subsection{Questionnaire}

1) What is American Literature?

2) When did you read an American novel, poem, play, essay or short story for the first time?
a. When I was in primary school
b. When I was in high school
c. When I entered the university.

3) How many American literary texts did you study in high school?

4) Did you like the texts that you studied?

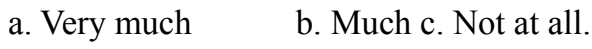

5) If you did not like these texts, say why:
a. They were boring
b. They were difficult to understand

c. They were badly taught

d. They did not reflect my own life experience.

6) Since your admission into the university, how many American literary texts have you read?
a. Poems:
b. Essays:
c. Plays:
d. Novels

7) I find the approach/method that my University lecturers use to teach American literature
a. very good
b. good
c. bad
d. very bad. 
8) If this approach is bad, suggest some changes that can improve it.

\subsection{Results}

The analysis of the students' answers provides the following statistics: Out of the 191 respondents, $86 \%$ defined American literature as literature that reflects the history, life and experiences of Americans. As for question two, $3.66 \%$ of the respondents read an American text for the first time when they were in primary school, $27.69 \%$ in high school, and $57.59 \%$ in the university. Question three shows that in high school, $65.44 \%$ of the 191 respondents read no American literary text and $32.98 \%$ read one text. Question four proves that $28 \%$ of the students who read some texts liked them very much, $31.41 \%$ liked them much and $25.69 \%$ did not like them at all. The reasons given for their aversion are stated in question five: $4.18 \%$ of the respondents observed that the texts were boring, $20.4 \%$ found them difficult to understand, $55.42 \%$ noted that they were badly taught, while $9.42 \%$ found that the texts did not reflect their life experiences. The answers to question six demonstrate that since their admission into the university, $34.55 \%$ of the respondents have read more than 6 poems, $36 \%$ have studied one to five essays, $36 \%$ have read one to five plays, and $47.12 \%$ have read one to five novels. Question seven reveals that $24.08 \%$ of the students find their university lecturers approach very good, $59.16 \%$ find it good, $10.99 \%$ assess it as bad, and $2.61 \%$ consider it very bad. In question eight the suggestions made by those who did not like the method range from the reduction of the number of books (14 students out of 191), provision of summaries of texts and critical material (8 students) and film projections (10 students).

\section{Discussion}

All the statistics dug out prove without doubt that the Cameroonian reader's response to American literature is lukewarm. The causes of this attitude towards this discipline are historical and academic: The country's colonial past, the very limited use of new technologies and the use of poor approaches to the teaching of literary texts.

\subsection{The Country's Colonial Past}

Cameroon, a former French and British colony, has inherited its former masters' educational systems, a fact which explains why the syllabi of high schools give preference to British and French literary texts. Colonial education was introduced in Cameroon by English Baptist missionaries John Clarke of Jericho, Jamaica, Dr. G.K. Prince, Joseph Merrick, Alexander Fuller, and Alfred Saker. The main goal of these missionaries was to gain converts who could read and understand the Bible and later preach the Christian creed (Ngoh, 1996). Besides its prime mission, colonial education framed the post-independence educational system of Cameroon which is divided into Francophone and Anglophone systems. Many Anglophone high school students are familiar with Shakespeare, D. H Lawrence and other British writers, while their Francophone counterparts are acquainted with Gustave Flaubert, Beaumarchais, and Guillaume Apollinaire, to mention just a few. When asked to name some American writers that they read or studied in high school, many respondents of the Department of English of the University of Yaoundé I cited Shakespeare, William Blake, Jane Austen, and George Orwell. Very few mentioned Ernest Hemingway and Richard Wright. Yet the same students easily cited American actors and films. This thus proves that official curricula established by the Cameroonian Ministry of Secondary Education accord very little or no space at all to American literary texts in both Anglophone and Francophone high schools. This fact thus leads to the Cameroonian reader's poor exposure to American literature, as evidenced by the previous statistical survey.

\subsection{Poor Approaches to the Teaching of Literature}

To the factor aforementioned, I will add a second one which is methodological, as the approaches used to teach a discipline may attract or repel the learners. It is a proven fact that literature appeals to sensibility; it may therefore be difficult for a Cameroonian reader to understand texts which dwell on American Transcendentalism, a handicap which forcibly leads to a lukewarm response. Graff (1992) observed that he disliked literature because it had no apparent application to his experience. It is therefore incumbent upon the teachers of literature to make it more accessible and attractive to their learners by linking it to the latter's life experiences. The last section of my article thus suggests among other strategies, the comparative approach as a means to boost the reading and teaching of American literature in Cameroonian academic institutions.

\section{Recommendations}

The following remedial strategies can change the Cameroonian readers' lukewarm attitude towards American literature.

\subsection{The American and Cameroonian Officials' Action}

In many African countries - Cameroon is not an exception - politicians decide about the courses and texts that must be taught in their schools. This therefore implies that the Yaoundé-based American Embassy and 
specifically the American Cultural Affairs officers may one way or the other, influence some of the decisions by suggesting the study of American literary texts in Cameroonian high schools. In the 1970s, students of lower and upper six classes of the Francophone system of education could study Hemingway's A Farewell to Arms, For Whom the Bell Tolls, and John Steinbeck's Of Mice and Men, Richard Wright's Native Son, Langston Hughes's poems and more. But today, at the time when the American government sponsors and monitors Susi programs on Contemporary American Literature, no American literary text is taught to the students of the aforementioned classes. The Susi program is a wonderful opportunity to convey American culture in Cameroon, as it targets both secondary and higher education. Contemporary American Literature, one of its main components shows the role that literature plays in the expansion of this culture. Yet how many grantees of this fellowship will actually teach and promote American literature in Cameroonian high schools if the curriculum of these schools does not include American literary texts? Teaching American literary texts in Cameroonian high schools does not forcibly lead to the invisibility or erasure of Cameroon Literature.

\subsection{The Use of Film, Video and Other Media}

From my investigation, it is clear that high school students who completely ignore American writers and their texts are acquainted with American films and actors. This is an avenue that should be exploited in some of our high schools and universities. Purves (1997) quoted in Richter (2000, p. 215) argues that:

We make a grave mistake if we see literature only as print; it has been only print for a brief period, two hundred years. For our students, and to a great extent for us, literature is a multimedia affair; this fact is at the heart of our personal and collective canon. All media should be at the heart of our literature classes... There is no reason why students should not deal with film, video, audio, hypermedia, and other forms of presentation.

If Purves's argument was pertinent in 1997 when it was made, in 2014, seventeen years later, it has become a rallying cry. In an era when new technologies of information and other technological advances make the reading of print texts more and more difficult to students, film, video, audio, hypermedia, and other forms of presentation should help to prop up this reading. To make this possible in Cameroonian academic institutions where literature is still a print affair, the American Embassy, and specifically the James Baldwin Resource Center of Yaoundé and other American cultural institutions in Cameroon should make their video sections (if they exist) accessible to teachers of American literature, even if these educationists may have to pay a loan fee to enable these cultural centers to equip their video sections with films produced from literary texts such as Eugene O'Neill's The Emperor Jones, Margaret Mitchell Gone with the Wind, Alice Walker's The Color Purple, Toni Morrison's Beloved, etc. However, the Embassy's efforts will not bear fruits if some Cameroonian high schools and universities which have electricity facilities do not cooperate. These academic institutions should buy the basic equipment: a TV set and a DVD to make the projections of these films possible. Although the large number of students in our university courses make such an endeavor difficult, this task can be carried out by tutorial masters who usually handle a smaller number of students. At the level of primary education, cartoons can be shown (David Crockett) and abridged versions of American short stories can be taught. All these efforts should be crowned by the American and Cameroonian political decision makers' will to match their cultural cooperation with their booming economic partnership. The might of a country must also be translated into its ability to make its literature known and read in "the four quarters of the globe."

Although political, economic and cultural policymakers may serve as leaven to the expansion of American literature in Cameroon, the prime movers of this process are teachers of this discipline. These educationists should adopt approaches which involve this literature in the fight against the evils that plague the Cameroonian society today. A teacher who teaches Wright's Black Boy should not only focus on racism. He/She should dwell more on the young boy's willpower, efforts, and eagerness to succeed despite his harsh economic and social environments. The second choice is nearer the Cameroonian youth who must today come to grips with unemployment, poor educational policies and precarious living. This thus leads to the last section which compares Joseph Bruchac's "Half a Blanket" and "The Boy and the Dish", a Native American short story and a Cameroonian folktale.

\subsection{The Comparative Approach to Literature: A Case Study}

The comparative study of the aforementioned short stories is a case study that underpins Graff's contention that literary criticism can change a student's aversion to literature into a real passion for it. Engaging the learner in critical debates makes him/ her discover that he/ she is able to give his/her own interpretations that can confirm or contradict other critics' views on the texts. The learner or reader thus becomes an active participant in the reading or learning process.

Langer (1994, p. 6) thus purports that: 
The thought-provoking literature class is an environment where students are encouraged to negotiate their own meanings by exploring possibilities, consider understandings from multiple perspectives, sharpen their own interpretations, and learn about features of literary style and analysis through the insights of their own responses. Responses are based as much on readers' own personal and cultural experiences as on the particular text and its author.

In other words, the reception of literature is conditioned by the way the reader or learner feels involved through his/her experiences, culture, and interpretations of the literary text.

The analysis of the archetypal pattern of the old wise man/old wise woman which pervades the Indian and Beba (Note 2) folktales is therefore just one of the possible interpretations of the two texts; it should be used to arouse and not to inhibit the learners' own interpretations.

Both tales centre on old age and its representations in Mohawk and Beba communities. Bruchac's "Half a Blanket" is the story of three men; a son, his father, and grandfather. When game becomes rare and the son's father can no longer feed his family, he decides to get rid of his own father, who is too old, weak and hardly walks. As the grandfather has become a burden, his grandson is summoned by his father to take him to the forest and abandon him with just a deerskin blanket to keep him warm while he awaits his death. But the grandson, who disapproves of his father's decision, takes his grandfather to the forest, cuts the blanket into two and brings back half a blanket home. When asked by his father why he has brought back half a blanket, the son replies that "when you grow old and there is nothing more that we can do, I will wrap this blanket around your shoulders after I abandon you in the forest" (2003, p. 143). This reply stirs the father's conscience and he orders his son to bring his grandfather back home.

The second tale, "The Boy and the Dish" translated by Juliana Makuchi Abbenyi and Louis-Marie Ongoum, revolves around an orphan, his wicked stepmother, her son, and an old woman. The stepmother's ill treatment of the deceased first wife's son leads to the orphan's journey to the stream and his fortuitous encounter with the old woman who welcomes him and asks him to cook some plantain peelings and chicken droppings. The obedient orphan follows the old lady's instructions and when he has to return home, he is given the dish and a dirty egg that he must break in front of his father. The boy, who heeds the old woman's advice, becomes wealthy.

As his wealth angers his stepmother, she sends her own son to face the same hurdles. But the spoiled child, who is not used to doing household chores, does not understand why the old woman should ask him to cook plantain peelings and chicken droppings. His disobedience and scorn for the old woman make him choose the shiny white egg and not the dirty one that the old woman asks him to take. As he reaches his mother's home, he breaks the egg far from the other village dwellers. Instead of getting the so much awaited wealth, both mother and son reap death. This tale is a well known folktale in the various tribes of Cameroon. It can sometimes represent an orphan girl and a lost spoon (Note 3), but it always focuses on the central role of the old woman, her advice to the young boys or girls who visit her, and the latter's responses to her admonitions.

The two tales present two antithetical perceptions of old age. Its mythical dimension inscribed in the archetypal pattern of the old wise man/old wise woman, and the realistic dimension of old age and its worries in modern African and Indian societies. In the tales, two groups of characters exemplify the two opposed perceptions. In "Half a Blanket," three generations typify the life cycle, the grandson, the father and the grandfather. The grandfather stands for the wise old man who quietly accepts his own son's decision to abandon him in the forest. Likewise, the grandson embeds veneration of old age; he believes that old men are part of the natural life cycle. They should not be cut off from the other members of the family because they are part of a sort of great chain of being, and their severance from the family means disintegration of the latter. His reply to his father elucidates the relationship between self and other in the Mohawk community. The grandson abides by what J. Olowo Ojoade, quoted in Ongoum and Tchewo (1988, p. 111) calls the "Universal Golden Rule" which is to "Live and let Live". This rule also pervades the Cameroonian tale and it is embedded in the wise old woman who helps both the obedient orphan and the disobedient boy. Like the grandson in "Half a Blanket," the orphan in "The Boy and the Dish" respects the elders and heeds the old lady's advice. The two youths' reverence for old age symbolizes the mythical dimension of the latter in the traditional Indian and Cameroonian societies.

In contrast, the father in "Half a Blanket", the wicked stepmother and the disobedient boy in "The Boy and the Dish" represent old age in modern Indian and Cameroonian societies. For the father in Bruchac's tale, old age means burden for others. The grandfather is a heavy load he cannot afford to carry in times of hardships. The scarcity of game becomes a factor of division and disintegration of the family. The grandfather's son is thus an example of the modern adult who toils day and night to feed his family, but who, at the end, is compelled by hard times to make difficult choices. He has to sacrifice his own father in order to spare food for the younger ones. 
Through the father's choice, one perceives the gradual erosion of old values.

Like the father in the Indian tale, the wicked woman and her son jettison the old African rule of "Live and let live," as well as the rule of obedience and submissiveness to the elders.

The stepmother in the second tale is the embodiment of selfishness, jealousy and wickedness. She stands for the modern Cameroonian society where unemployment, food scarcity, and the spirit of acquisitiveness are more and more threatening the Cameroonian values of solidarity and hospitality. Her ill treatment of the orphan and her envy question the image of the traditional African Great Mother - the Jungian mother earth - that was the rallying factor in so many traditional African societies. Her disobedient son-who scorns the old woman and refuses to heed her advice - is the image of many Cameroonian young men and women who, today, associate old age with burden and sorcery. For these young people, one has to shun old men and women. In modern African societies, the mythical dimension of old age is dying away and being replaced by disrespect for old values.

The Indian and the Cameroonian tales do not only have similar themes, but also analogous narrative strategies. The opening lines of the two tales are similar: "Long ago, there was a time when game became scarce and life was not easy for the people" (Bruchac, 2003, p. 142) and "Once upon a time there lived a man who had two wives. The first wife had a son. The second wife was also blessed for she too had a son. But the first wife did not live to see old age (Ongoum \& Tchewo, 1988, p. 83). The beginning of the two tales presages hardships and the characters' responses to the harsh social environment. They may adopt compassion and help one another, or endorse the egoistic attitudes of the father and the stepmother. Both tales use dialogues which make the listener or reader participate in the events as the story unfolds. As Ongoum $(1988$, p. 119) remarks, the tale enables one to move from one universe to the other through a correlative variation of the time factor, thanks to its malleability in the mouth of the storyteller, to its adaptability to all the audience, and to various circumstances, as it borrows from other genres, without altering its specificity.

The malleability of the tale and the storyteller's prowess enhance action and performance that include not only the teller but the audience as well. In this instance, the storyteller's word is power. Ongoum rightly purports that African traditional literature is the art of the word, and the power of tradition resides in the word. In her article, Janette Murray (1985, p. 155) quotes Margot Astrov who observes that "the Indian believe(s) that the word is power". The belief in the power of the word is thus shared by the Cameroonian and Indian writers, storytellers and communities. Bruchac, who lived and taught in West Africa, is familiar with African proverbs that precisely illustrate this power of the word. The forest and the river are archetypal patterns that symbolize both death and rebirth. They are both the dark (subconscious) and awareness (consciousness). The grandson's trek to the forest with his grandfather portrays the father's egocentrism and the death of ethical values such as compassion and filial love; however, these dead values are resurrected by the grandson. In the same light, the stepmother's wickedness is negated by the orphan's rebirth due to his immersion in the river.

The categories of Indian tales that Stith Thompson (1968, p. xvii), quoted in Murray (1985, p. 156), brings out are similar to the different categories of Cameroonian tales: 1) Mythological stories: These stories deal with the world before it was in the present state. They explain the origins of animals, or tribes, or objects, or ceremonies, the universe itself. 2) Trickster tales: These tales relate the deeds of the trickster. Sometimes the buffoon is a human being, but more often he is an animal endowed with human characteristics. 3) Hero tales: These tales represent the lives of human beings under conditions at least remotely resembling the present. Transformations, magic, otherworld journeys, ogres, and beast marriages are common, but the characters are thought of as distinctly human. 4) Miscellaneous tales: There are other tales which are definitely borrowings from Europeans and from the Bible. These tales are somewhat like the myths of the Greeks, but animals figure more prominently in the Indian stories. Many Cameroonian tales also represent animals. In Charles Binam Bikoi and Emmanuel Soundjock's Les Contes du Cameroun/Tales from Cameroon (1984), the titles of most of the stories show the recurrence of animals: "The Orphan and the Chimpanzee", "The Wicked Panther", "Why Pig Has No Horns", "Leopard and Monkey" and "Soo- Antilope and Emvulu-Hart".

\section{Conclusion}

This article has shown that the Cameroonian readers' poor response to American literature results from the country's colonial past, the Cameroonian public's limited exposure to this discipline and the approaches used to teach it. The article has suggested some avenues that can improve the reception of this literature in Cameroon: The action of the Yaoundé-based American Embassy and cultural centers, the use of films and other technologies of information, and the comparative approach to literature. A comparative study of an American short story and a Cameroonian tale has demonstrated that both stories have a lot of similarities as far as content and form are concerned. This has led to the conclusion that American literature can aptly tackle the problems of the 
twenty-first century Cameroonian reader. Consequently, the teachers of this discipline should adopt approaches that not only make room for the learners' own interpretations of the literary texts, but also involve the study of these texts in the fight against the ills that plague Cameroon today.

\section{References}

Abbenyi, M. J., \& Ongoum, L. M. (1988). The Boy and the Dish. In L. M. Ongoum, \& C. Tchewo (Eds.), Oral Literature in Africa Today: Theoretical and Practical Approaches (pp. 83-87).Yaoundé: Projet Guelph.

Ashcroft, B., Griffiths, G., \& Tiffin, H. (1989). The Empire Writes Back. London \& New York: Routledge. http://dx.doi.org/10.4324/9780203426081

Bikoi, C. B., \& Soundjock, E. (1984). Les Contes du Cameroun (2nd ed.). Yaoundé: CEPER.

Bruchac, J. (2003). Half a Blanket. Our Stories remember: American Indian History, Culture, and Values through Storytelling (pp. 142-143). Colorado: Fulcrum Publishing.

Bruchac, J. (2011). Foreword. Maurice Kenny: Not Through Height. In P. M. Kelsey (Ed.), Maurice Kenny: Celebrations of a Mohawk Writer (pp. ix-xii). New York: State University of New York Press.

Conn, P. (1989). Literature in America. New York: C.U.P.

Gadamer, H. G. (1990). Truth and Method (J. Weinsheimer, \& D. G. Marshall, Trans., 2nd ed.). New York: Continuum International Publishing Group.

Graff, G. (1992). Disliking Books at an Early Age. In D. H. Richter (Ed.), Falling into Theory: Conflicting Views on Reading Literature (pp. 41-48). Boston \& New York: Bedford/St. Martin's.

Guerin, W. L., Labor, E., Morgan, L., Reesman, J. C., \& Willingham, J. R. (1999). A Handbook of Critical Approaches to Literature. New York: O.U.P.

Jung, C. G. (1969). The Structure and Dynamics of the Psyche (2nd ed.). Princeton, New Jersey: Princeton University Press.

Langer, J. A. (1994). A Response-Based Approach to Reading Literature. National Research Center on Literature Teaching and Learning Report Series, 6. Retrieved from http://www.albany.edu/cela/reports /langer/langerresponsebased.pdf

Murray, J. K. (1985). What Is Native American Literature? The Canadian Journal of Native Studies, 2, 151-166.

Ngoh, V. J. (1996). History of Cameroon since 1800. Limbe: Presbook.

Nkwetisama, C. M. (2013). Literature and TEFL: Towards the Reintroduction of Literatures in English in the Francophone Secondary School Curriculum in Cameroon. International Journal of Applied Linguistics \& English Literature, 2(6), 169-179. http://dx.doi.org/10.7575/aiac.ijalel.v.2n.6p.169

Ojoade, O. J. (1988). African Moral Education Seen Through Oral Literature Together with Foreign Analogues. In L. M. Ongoum, \& C. Tcheho (Eds.), Oral Literature in Africa Today: Theoretical and Practical Approaches (pp. 99-118). Yaoundé: Projet Guelph.

Ongoum, L. M. (1988). Contes, Conteur et Société. In L. M., Ongoum, \& C. Tcheho (Eds.), Oral Literature in Africa Today: Theoretical and Practical Approaches (pp. 119-125). Yaoundé: Projet Guelph.

Ongoum, L. M., \& Tcheho, C. (Eds.). (1988). Oral Literature in Africa Today: Theoretical and Practical Approaches. Proceedings of the international symposium organized in Yaoundé. Yaoundé: Projet Guelph.

Oslon, D. R., \& Torrance, N. (Eds.). (2009). The Cambridge Handbook of Literacy. Cambridge: Cambridge University Press.

Porter, J., \& Roemer, K. M. (Eds.). (2005). The Cambridge Companion to Native American Literature. New York: C.U.P. http://dx.doi.org/10.1017/CCOL0521822831

Purves, A. (1997) Telling Our Story about Teaching Literature. In D. H. Richter (Ed.), Falling into Theory: Conflicting Views on Reading Literature (pp. 210-18). Boston \& New York: Bedford/St. Martin's.

Roemer, K. M. (2005). Introduction. In J. Porter, \& K. M. Roemer (Eds.), The Cambridge Companion to Native American Literature (pp. 1-24). New York: Cambridge University Press. http://dx.doi.org/10.1017/CCOL0521822831.001

Singh, M. K. M. (2014). Challenges in Academic Reading and Overcoming Strategies in Taught Master Programmes: A Case Study of International Graduate Students in Malaysia. Higher Education Studies, 4(4). http://dx.doi.org/10.5539/hes.v4n4p76 
Spivak, G. C. (2003). Death of a Discipline. Columbia: Columbia University Press.

Tate, A., (Ed.). (1960).The Language of Poetry. New York: Russell.

Thompson, S. (1968). Tales of the North American Indian. Bloomington: University of Indiana Press.

Tötösy de Zepetnek, S. (1998).Comparative Literature: Theory, Method, Application. Amsterdam-Atlanta, Ga: Rodopi.

Vietto, A. (2010). Research Guide to American Literature: Early American Literature 1776-1820. New York: Facts on File, Inc. Retrieved from http://www.factsonfile.com

Watts, A. W. (1954). Myth and Ritual in Christianity. New York: Vanguard Press.

Wheelwright, P. (1962). Metaphor and Reality. Bloomington: Indiana University Press.

\section{Notes}

Note 1. In Research Guide to American Literature: Early American Literature, Angela Vietto notes that there were several regionally affiliated groups of poets worth noting. The one most familiar in literary criticism has been called the Connecticut Wits (earlier the Hartford Wits or the "wicked wits"). This group of young men, mostly graduates of Yale, included Joel Barlow, Timothy Dwight IV, David Humphreys, John Trumbull, Lemuel Hopkins, Richard Alsop, and Theodore Dwight (p. 6).

Note 2. Beba is a community in the Menchum Division, a large division in the North West Region of Cameroon.

Note 3. In Binam Bikoi and Emmanuel Soundjock's Les Contes du Cameroon/Tales from Cameroon, the boy has been replaced by a female orphan and the dish by a spoon, thus the title of the tale "La Cuillère Casseé"/ "The Broken Spoon" (pp. 244-258).

\section{Copyrights}

Copyright for this article is retained by the author(s), with first publication rights granted to the journal.

This is an open-access article distributed under the terms and conditions of the Creative Commons Attribution license (http://creativecommons.org/licenses/by/3.0/). 